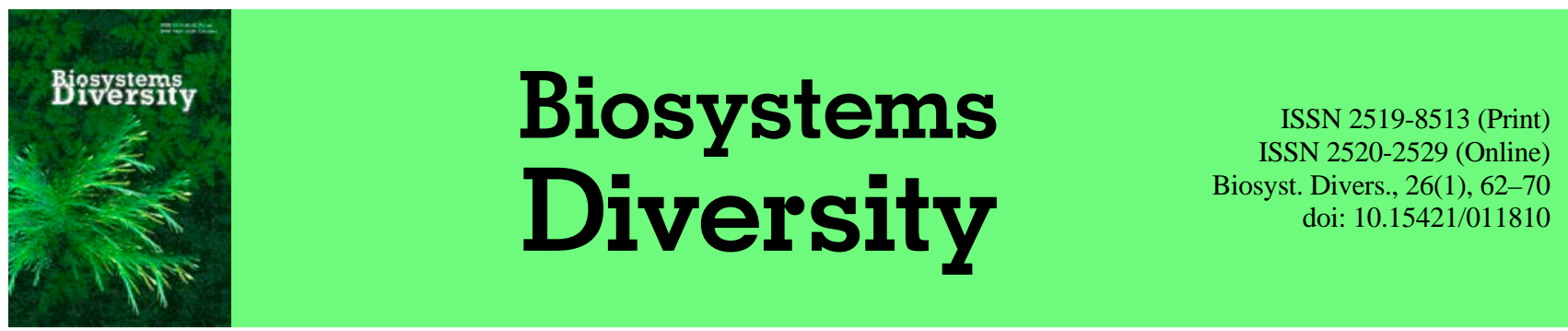

\title{
Biodiversity and dynamics of plant groups of Chebket El Melhassa region (Algeria)
}

\author{
B. Maamar ${ }^{1}$, B. Nouar $^{2}$, L. Soudani ${ }^{3}$, M. Maatoug ${ }^{3}$, M. Azzaoui ${ }^{4}$, M. Kharytonov ${ }^{5}$, O. Wiche ${ }^{6}$, O. Zhukov $^{7}$ \\ ${ }^{1}$ El Wancharissi University Center, Tissemsilt, Algeria \\ ${ }^{2}$ Abu Bakr Belkaid University, Tlemcen, Algeria \\ ${ }^{3}$ Ibn Khaldoun Tiaret University, Tiaret, Algeria \\ ${ }^{4}$ Ex Hall Technology, Mostaganem, Algeria \\ ${ }^{5}$ Dnipro State Agrarian and Economic University, Dnipro, Ukraine \\ ${ }^{6}$ Institut für Biowissenschaften, Freiberg, Germany \\ ${ }^{7}$ Oles Honchar Dnipro National University, Dnipro, Ukraine
}

Article info

Received 25.01.2018

Received in revised form 28.02.2018

Accepted 01.03.2018

El Wancharissi University Center, Route Bougara, Ben Hamouda, 38004, Tissemsilt

E-mail: benchohra_19@hotmail.fr

Abu Bakr Belkaid University, 22, Abi Ayed st., 22, Abdelkrim Fg Pasteur, B.P 119, 13000, Tlemcen, Algeria.E-mail: nouar.belkacem@hotmail.fr

Ibn Khaldoun Tiaret University, BP P 78 Zaâroura 14000, Tiaret, Algeria

E-mail:maatoug.moh@gmail.com

Ecole Superieure d'Agronomie, Ex Hall Technology, Khauba Road, 27000, Mostaganem, Algeria.E-mail:moha-1500@outlook.com

Dnipro State Agrarian and Economic University, Sergey Yefremov st, 25, Dnipro, 49600, Ukraine. E-mail: kharytonov.m.m@dsau.dp.ua

AG Biologie/Ökologie, Institut für

Biowissenschaften, TU Bergakademie Freiberg Leipziger st., 29, Freiberg, D-09599, Germany. E-mail:oliverwiche@ioeztu-freiberg.de

Oles Honchar Dnipro National University, Gagarin ave., 72, Dnipro, 49010, Ukraine. Tel.: +38-056-760-84-38.

E-mail: zhukov_dnipro@ukr.net

\begin{abstract}
Maamar, B., Nouar, B., Soudani, L., Maatoug, M., Azzaoui, M., Kharytonov, M., Wiche, O., \& Zhukov, O. (2018). Biodiversity and dynamics of plant groups of Chebket El Melhassa region (Algeria). Biosystems Diversity, 26(1), 62-70. doi: 10.15421/011810
\end{abstract}

This article examines phytoecological aspects of plant groups in the Chebket El Melhassa region (Tiaret-Ouest Algérien) by several types of analysis: biological, biogeographic and statistical. From the plant analysis, a list of 103 taxa distributed in 36 families was compiled, biologically characterized by a dominance of therophytes (45.6\%) with species of the Mediterranean biogeographic type 20 species (19.8\%) assuming particular importance. The ordination of the plant community was performed in the search for the optimum solution based on correlation with environmental factors, estimated using the phytoindication approach. The results reveal that the plants represented in the community, mostly prefer strongly lit places. Phytoindication shows a warm sub Mediterranean climate. Continentality corresponds to the sub-oceanic climate. The moisture regime ranges from strongly dry to dry soil. The plant community is formed on moderately acid soils. Plants are able to grow on both strongly acidic and neutral soils. The soil is very poor or poor in nitrogen. A four dimension variant of multidimensional scaling procedure was selected as the most appropriate decision. Dimensions selected after nonmetric multidimensional scaling were interpreted by computing weighted average scores of ecological factors for ordination configuration. Four of the plant species clusters were found to be the optimal solution on the basis of the Calinsky-Harabasz criteria. The clusters can be viewed as a functional group. Functional group A is quite diverse and represented by 42 species. This functional group is closest to the community optimum because in all four space dimensions the corresponding cluster is near the origin, which corresponds to the most typical ecological conditions. Species that constitute the group B prefer minimum values of dimension 2. This indicates a preference for illuminated sites with high temperature regime and low soil humidity. This group includes 32 species. A feature of group $\mathrm{C}$ is that it is located in the area of maximum values for dimension 2 . Thus, this functional group is opposite to functional group B. This indicates a preference of species included in the functional group $\mathrm{C}$ for wetter soils. Functional group $\mathrm{C}$ comprises 21 species. Functional group D differs considerably from all others in its ecological characteristics. The difference is in the preference for minimum values for measurement 1 . This suggests that more acid soils are optimal for a given functional group. Functional group E comprises 8 species.

Key words: Phytoecology, vegetation dynamics, F.A.C, Chebket El Melhassa, Tiaret

\section{Introduction}

In the global context of preserving biodiversity, the study of the flora and vegetation of the Mediterranean basin is of great interest because of its richness linked to the heterogeneity of historical, paleogeographic, paleoclimatic, ecological and geological factors and the secular impact of anthropogenic pressure (Quézel et al., 1980).

Arid and semi-arid regions in North Africa are currently experiencing degradation of natural resources. Vegetation formations (forests, pre-forests, matorrals and steppes) are regressing under climaticanthropic impact. This dual action leads to physiognomic and landscape changes, which have led to major changes in bio-resources (Hasnauoi \& Bouazza, 2015). For example, in Algeria, the forest heritage, like that of the other Mediterranean zones, has experienced a continuous regression due to a combined action of man (deforestation, overgrazing) and climate (decaying summer, irregular rains, violent showers). This evolution has led to the substitution of the original mesophytic vegetation, by a xerophytic vegetation to varying degrees (Benabadj \& Bouazza, 2001).

Phytocenoses consists of species of which the ecological amplitude overlap. Each species has an indicator value, but an indication cannot be made on the basis of the one species. The composition of species can be used to quantify the properties of the environment, which cannot easily be measured directly, unlike, for example, pollution (Austin, 2013). Phytoindicator scales can be considered as markers of environmental properties. Correctly recorded vegetation plots are less influenced by spatial and temporal variability than single field measurements of environmental factors (Horsák et al., 2007). The composition reflects the distribution of the resulting group of species that make up a phytocoenosis.

Ellenberg indicator values represent the realized ecological optimum plant species in the form of ordinal digits. Weighted indicator 
values for plants of the group are used as a surrogate assessment of the values of the ecological factors (Diekmann, 2003). The disadvantages of the method of average weighted indicator values include the fact that this method does not take into account the point the absence of species. So it can reach the ironic conclusion that telegraph poles demonstrate optimum pH (Ashby, 1936). From a purely mathematical standpoint, the method of average values weighted indicator values is not acceptable, as indicating the value measured in the ordinary scales. However, it is postulated that the ordinal nature of the Ellenberg indicator values is much less important in comparison with the response curve types, which should be symmetrical (ter Braak \& Gremmen, 1987). In this case, mean and median are largely indistinguishable (Diekmann, 2003). So there are no practically significant arguments that could deny the use of the average values for the purposes of phytoindication (Seidling \& Fischer, 2008). Furthermore it was shown that curve distributions that are close to Gauss symmetrical average values give a reliable phytoindication score (ter Braak \& Looman, 1986).

Previous studies (Cherifi et al., 2011; Stambouli-Meziane \& Bouazza, 2012; Benabadji et al., 2014), on the flora and its diversity in the west of Algeria, reveal the degree of disturbance of these ecosystems, where anthropozoic factors play a major role in the organization of vegetation structures. Given the magnitude of these phenomena, which is constantly increasing, phytoecological studies are essential criteria for any conservation strategy.In this respect, our vegetational and floristic study of the Chebket El Melhassa region (Tiaret, West Algeria) is of great interest.

The purpose of this article is to perform the ordination of the plant community in the search for the optimum solution based on correlation with environmental factors, estimated using the phytoindication approach.

\section{Materials and methods}

Chebket El Melhassa belongs to the commune of Faidja, it is located about $90 \mathrm{~km}$ south of the capital of the wilaya of Tiaret (Fig. 1). It is bordered to the North by the municipalities of Nadorah and Sidi Abdelghanie, to the West by the municipality of Naïma, to the East by the municipality of Zmalet Emir Abdelkader and to the South by the Wilayas of Djelfa and Laghouat. The climate is Mediterranean with an average rainfall of $269.47 \mathrm{~mm} /$ year, the minimum average of the coldest month (m) is $3.01^{\circ} \mathrm{C}$ and the maximum average of the warmest month (M) is $38.08{ }^{\circ} \mathrm{C}$. The dry period is more or less long, extending from March to November (Benkhettou et al., 2015).

The sigmatist Braun-Blanquet (Braun-Blanquet, 1951) phytosociological method (floristic surveys) was used. In the Mediterranean region, the minimum area is between 100 and $400 \mathrm{~m}^{2}$ for forestry groups, and between 50 and $100 \mathrm{~m}^{2}$ for matorral (Benabid, 1984).

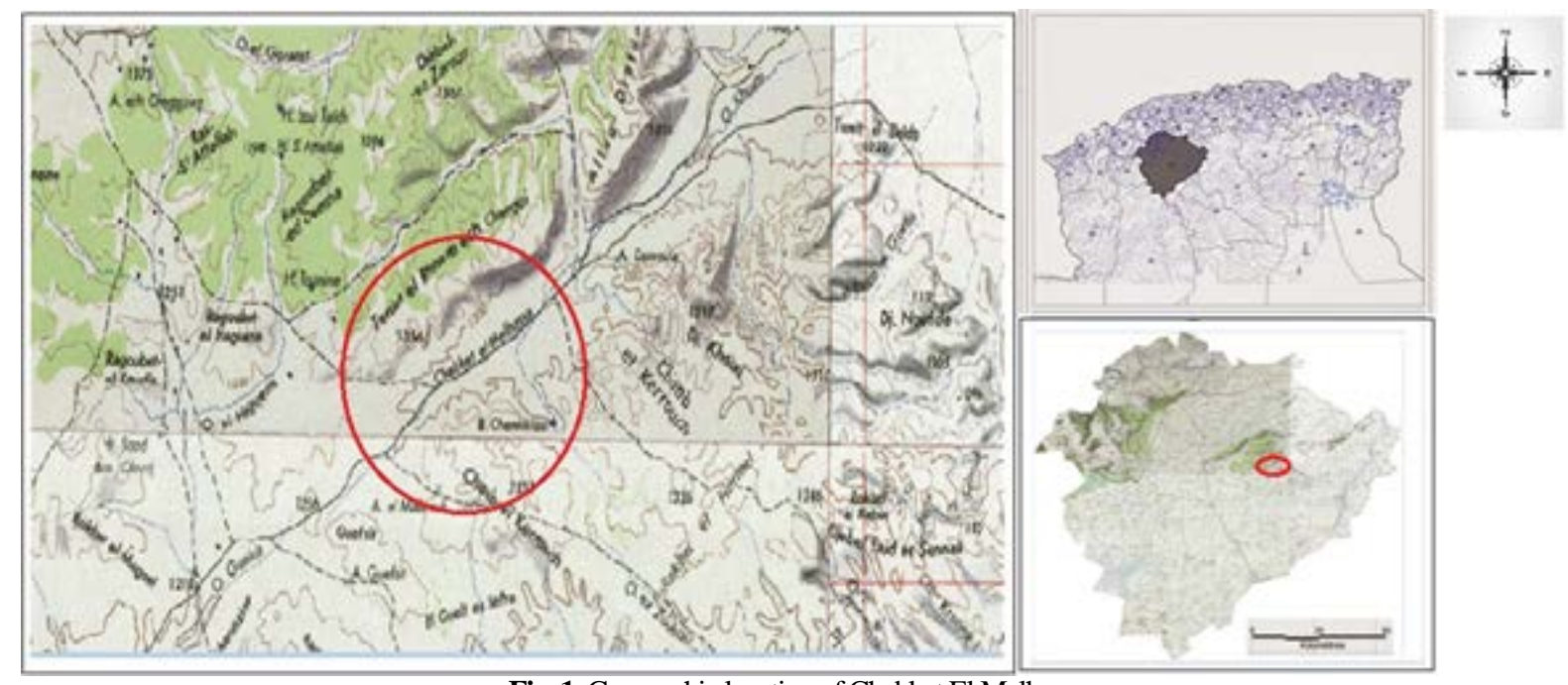

Fig. 1. Geographic location of Chebket El Melhassa

In our case, we selected an area of $100 \mathrm{~m}^{2}$. 30 surveys were carried out during a favourable floristic season (March to June) of 2015, each vegetation survey consisted of an exhaustive inventory of all the plant species encountered according to strata (tree, shrub and herbaceous) and each species was accompanied by two indices: abundance-dominance and sociability. The identification of taxa was made from the new flora of Algeria (Quézel \& Santa, 1962). The identification of species took a long time because of lack of experts in botany. The perturbation index (PI) was calculated from the formula (Loisel \& Gamila, 1993):

$$
\mathbf{P I}=\frac{\text { numbers of chamephytes }+ \text { number of therophytes }}{\text { total number of species }} * \mathbf{1 0 0} \text {. }
$$

Ellenberg indicator values (1974) include: L-scale of illumination / shading (9 classes, Light Regime), T-scale of thermo climate (9 classes, temperatures), K-scale of climate continentality (9 classes, continentality of climate), F-scale of soil moisture (9 classes, humidity), R-scale of soil acidity (9 classes, acidity), and $\mathrm{N}$-scale of soil nitrogen ( 9 classes, nutrients availability). Estimation of values of environmental factors was carried out using the method of average weighted values of indicator scales taking into account the protective coating of plants. Ellenberg indicator values were modified to reflect local differences in species ecological properties, e.g. in Switzerland, Poland, British Isles and Italy (Landolt, 1977; Hill et al., 1999; Zarzycki, 1984; Pignatti et al., 2005). Ellenberg-Pignatti values from Italy were shown to be useful for phytoindication purposes in the Mediterranean ecosystems (Vitasović Kosić et al., 2017). For the plant species which are not included in the
Pignatti list, the indicator values were calculated as the weighted average of ecological factors in the sites of detection of these plants.

To decrease the dimension of the plant table, nonmetric multidimensional scaling was applied (Minchin, 1987). As measures of distance between sample points in the community space, the following metrics have been used: Euclidean, Manhattan, Gower, Bray-Curtis, Kulczynski, Morisita, Horn-Morisita, Cao, Jaccard, Mountford, RaupCrick, Canberra, Chao (Oksanen, 2017). The selection of appropriate distance metric and variants of primary data preliminary transformation was made on the basis of Spearman rank correlations coefficients between dissimilarity indices and gradient separation (Legendre \& Gallagher, 2001). Multidimension scaling was conducted using library ade4 (Dray et al., 2007) in the environment R (R Core Team, 2016).

\section{Results and discussion}

The inventoried flora has about 103 species, belonging to 36 families and 87 genera (Table 1). The Gymnosperms represent only $3.0 \%$, whereas the Angiosperms dominate widely with $97.0 \%$ with (72.5\% for the Eudicots and $24.5 \%$ for the Monocots). The distribution of families is heterogeneous. We noticed the dominance of the Asteraceae family with (22.3\%), followed by Poaceae (12.6\%), Brassicaceae, Caryophylaceae and Lamiaceaes in third position with the same percentage (5.8\%), followed by Apiaceaes (4.9\%) and Cistaceaes (3.9\%) (Fig. 2). Among the other families, 22 are mono-generic (0.9\%) 
such as Asphodelaceaes, Convolvulaceaes and Plantaginaceaes and one (1) other family is mono-specific, the Lauraceae family.

\section{Table 1}

Flora taxonomy structure and Ellenberg indicator values

\begin{tabular}{|c|c|c|c|c|c|c|c|c|c|}
\hline \multirow{2}{*}{ No } & \multirow{2}{*}{ Family } & \multirow{2}{*}{ Таха } & \multirow{2}{*}{$F G$} & \multicolumn{6}{|c|}{ Ellenberg indicator values } \\
\hline & & & & $L$ & $T$ & $K$ & $F$ & $R$ & $N$ Source \\
\hline & Alliaceae & Allium subhirsutum L. & $\mathrm{A}$ & 8 & 9 & 4 & 2 & 4 & 2 Pignatti \\
\hline 2 & & Pistacia atlantica Desf. & $\mathrm{B}$ & 9 & 8 & 4 & 3 & 5 & 3 Estimated \\
\hline & -Anacar- & P. lentiscus L. & $\mathrm{A}$ & 1 & 1 & 5 & 2 & 5 & 2 Pignatti \\
\hline 4 & & P. terebinthus L. & $\mathrm{B}$ & 9 & 8 & 5 & 2 & 7 & 2 Pignatti \\
\hline 5 & & Ammi majus L. & $\mathrm{A}$ & 11 & 9 & 5 & 4 & 5 & 2 Pignatti \\
\hline 6 & & Bupleurum rotundifolium L. & $\mathrm{A}$ & 8 & 7 & 5 & 3 & 9 & 4 Pignatti \\
\hline 7 & Apiaceae & Daucus carota (Desf.) Batt. & $\mathrm{B}$ & 8 & 6 & 5 & 4 & 5 & 4 Pignatti \\
\hline 8 & & Eryngium campestre L. & $\mathrm{B}$ & 9 & 7 & 5 & 3 & 8 & 3 Pignatti \\
\hline 9 & & Ferula communis L. & $\mathrm{B}$ & 9 & 8 & 5 & 3 & 5 & 2 Pignatti \\
\hline & $\begin{array}{l}\text { Aspara- } \\
\text { gaceae }\end{array}$ & Asparagus officinalis L. & $\mathrm{C}$ & 8 & 8 & 5 & 5 & 5 & 5 Pignatti \\
\hline & $\begin{array}{l}\text { Asphode- } \\
\text { laceae }\end{array}$ & $\begin{array}{l}\text { Asphodelus microcarpus } \\
\text { Salzm et Viv. }\end{array}$ & A & 1 & 9 & 4 & 2 & 3 & 5 Pignatti \\
\hline 12 & & $\begin{array}{l}\text { Anacyclus cyrtolepidioides } \\
\text { Pomel }\end{array}$ & $\mathrm{D}$ & 10 & 8 & 5 & 3 & 6 & 3 Estimated \\
\hline 13 & & Artemisia herba-alba Asso & $\mathrm{A}$ & 9 & 8 & 4 & 3 & 5 & 3 Estimated \\
\hline 14 & & Atractylis aristata Batt. & $\mathrm{C}$ & 9 & 8 & 4 & 3 & 5 & 3 Estimated \\
\hline 15 & & A. cancellata L. & $\mathrm{C}$ & 11 & 8 & 5 & 2 & 6 & 2 Pignatti \\
\hline 16 & & A. humilis L. & $\mathrm{B}$ & 10 & 8 & 4 & 3 & 5 & 3 Estimated \\
\hline 17 & & A. carduus (Forssk.) C. Chr. & $\mathrm{A}$ & 9 & 8 & 4 & 3 & 5 & 3 Estimated \\
\hline 18 & & Bellis sylvestris L. & $\mathrm{A}$ & 5 & 8 & 4 & 3 & 3 & 3 Pignatti \\
\hline 19 & & Calendula arvensis L. & $\mathrm{A}$ & 7 & 8 & 5 & 3 & 8 & 5 Pignatti \\
\hline 20 & & Carduus nutans L. & $\mathrm{D}$ & 8 & 8 & 5 & 3 & 8 & 6 Pignatti \\
\hline 21 & & C. pycnocephalus L. & $\mathrm{A}$ & 7 & 8 & 4 & 3 & 5 & 3 Pignatti \\
\hline 22 & & Carlina gummifera (L.) Less. & $\mathrm{B}$ & 11 & 11 & 5 & 1 & 7 & 1 Pignatti \\
\hline 23 & & Catananche caerulea L. & $\mathrm{C}$ & 11 & 8 & 3 & 4 & 6 & 2 Pignatti \\
\hline 24 & & Centaurea pullata L. & A & 9 & 8 & 4 & 3 & 5 & 3 Estimated \\
\hline 25 & & Glebionis segetum (L.) Fourr. & $\mathrm{B}$ & 7 & 6 & 4 & 5 & 5 & 5 Pignatti \\
\hline 26 & & Echinops spinosissimus Turra & $\mathrm{B}$ & 11 & 12 & 3 & 2 & 5 & 2 Pignatti \\
\hline 27 & & Hypochaeris radicata L. & $\mathrm{D}$ & 9 & 8 & 4 & 2 & 6 & 1 Pignatti \\
\hline 28 & & $\begin{array}{l}\text { Launaea arborescens (Batt.) } \\
\text { M. }\end{array}$ & B & 10 & 8 & 4 & 3 & 6 & 3 Estimated \\
\hline 29 & & $\begin{array}{l}\text { Leucanthemum paludosum } \\
\text { (Poir.) Bonnet \& Barratte }\end{array}$ & B & 9 & 8 & 4 & 3 & 5 & 3 Estimated \\
\hline 30 & & Matricaria chamomilla L. & $\mathrm{B}$ & 7 & 5 & 5 & 6 & 5 & 5 Pignatti \\
\hline 31 & & Scolymus hispanicus L. & $\mathrm{B}$ & 11 & 8 & 5 & 3 & 5 & 2 Pignatti \\
\hline 32 & & $\begin{array}{l}\text { Podospermum laciniatum } \\
\text { (L.) DC. }\end{array}$ & A & 7 & 8 & 6 & 3 & 8 & 3 Pignatti \\
\hline 33 & & $\begin{array}{l}\text { Taraxacum obovatum } \\
\text { (Willd.) DC. }\end{array}$ & A & 7 & 6 & 4 & 4 & 6 & 6 Pignatti \\
\hline 34 & & Artemisia campestris L. & $\mathrm{A}$ & 9 & 6 & 5 & 3 & 5 & 2 Pignatti \\
\hline 35 & & Borago officinalis L. & $\mathrm{A}$ & 7 & 8 & 5 & 3 & 5 & 5 Pignatti \\
\hline 36 & Boragi- & Echium humile Desf. & $\mathrm{A}$ & 10 & 8 & 4 & 3 & 5 & 3 Estimated \\
\hline & naceae & $\begin{array}{l}\text { Lappula redowskii Hornem } \\
\text { (Greene) }\end{array}$ & $\mathrm{C}$ & 9 & 8 & 4 & 3 & 5 & 3 Estimated \\
\hline 38 & & $\begin{array}{l}\text { Alyssum granatense Boiss. } \\
\text { \& Reut. }\end{array}$ & $\mathrm{D}$ & 9 & 9 & 4 & 2 & 7 & 1 Pignatti \\
\hline 39 & & Lepidium draba L. & $\mathrm{A}$ & 8 & 7 & 7 & 3 & 8 & 4 Pignatti \\
\hline 40 & & Matthiola lunata DC. & $\mathrm{C}$ & 9 & 8 & 4 & 3 & 5 & 3 Estimated \\
\hline 41 & & M.parviflora (Schousb.)R.Br. & $\mathrm{B}$ & 10 & 8 & 4 & 3 & 5 & 3 Estimated \\
\hline 42 & & Sisymbrium irio L & $\mathrm{B}$ & 8 & 8 & 5 & 3 & 7 & 5 Pignatti \\
\hline 43 & & Sinapis arvensis L. & $\mathrm{C}$ & 7 & 5 & 4 & 3 & 8 & 6 Pignatti \\
\hline$\overline{44}$ & & $\begin{array}{l}\text { Paronychia arabica (L.) } \\
\text { DC. }\end{array}$ & A & 9 & 8 & 4 & 3 & 5 & 3 Estimated \\
\hline 45 & & Paronychia argentea Lam. & $\mathrm{A}$ & 11 & 8 & 4 & 2 & 2 & 1 Pignatti \\
\hline 46 & & Silene gallica L & $\mathrm{B}$ & 8 & 9 & 5 & 3 & 2 & 1 Pignatti \\
\hline & $\begin{array}{l}\text { Caryo- } \\
\text { phylaceae }\end{array}$ & $\begin{array}{l}\text { Sclerocephalus arabicus } \\
\text { Boiss. }\end{array}$ & B & 9 & 8 & 4 & 3 & 5 & 3 Estimated \\
\hline 48 & & $\begin{array}{l}\text { Silene vulgaris (Moench) } \\
\text { Garcke }\end{array}$ & $\mathrm{D}$ & 8 & 8 & 5 & 4 & 7 & 2 Pignatti \\
\hline 49 & & $\begin{array}{l}\text { Telephium sphaerospermum } \\
\text { Boiss. }\end{array}$ & B & 9 & 8 & 4 & 3 & 5 & 3 Estimated \\
\hline 50 & Cheno- & Chenopodium murale L. & $\mathrm{B}$ & 8 & 7 & 5 & 4 & 5 & 9 Pignatti \\
\hline 51 & podiaceae & Haloxylon scoparium Pomel & $\mathrm{B}$ & 9 & 8 & 4 & 3 & 5 & 3 Estimated \\
\hline 52 & & Cistus albidus L. & $\mathrm{B}$ & 11 & 9 & 4 & 2 & 3 & 2 Pignatti \\
\hline 53 & & C. monspeliensis L. & $\mathrm{B}$ & 1 & 9 & 4 & 2 & 2 & 2 Pignatti \\
\hline 54 & Cistaceae & $\begin{array}{l}\text { Helianthemum hirtum (L.) } \\
\text { Miller }\end{array}$ & B & 11 & 11 & 3 & 1 & 2 & 1 Pignatti \\
\hline 55 & & $\begin{array}{l}\text { H. helianthemoides (Desf) } \\
\text { Grosser. }\end{array}$ & A & 9 & 8 & 4 & 3 & 5 & $3 \mathrm{E}$ \\
\hline
\end{tabular}

\begin{tabular}{|c|c|c|c|c|c|c|c|c|c|}
\hline \multirow{2}{*}{ No Family } & \multirow{2}{*}{ Таха } & \multirow{2}{*}{$F G$} & \multicolumn{7}{|c|}{ Ellenberg indicator values } \\
\hline & & & $L$ & $T$ & $K$ & & $R$ & & Source \\
\hline $\begin{array}{l}56 \text { Convol- } \\
\text { vulaceae }\end{array}$ & Convolvulus althaeoides L. & $\mathrm{D}$ & 8 & 9 & 4 & 3 & 5 & & Pignatti \\
\hline $\begin{array}{l}57 \text { Crassula- } \\
\text { ceae }\end{array}$ & Sedum album L. & B & 11 & 8 & 5 & 2 & 5 & & Pignatti \\
\hline 58 & Juniperus phoenicea L. & A & 11 & 8 & 5 & 2 & 4 & & Pignatti \\
\hline $\begin{array}{l}59 \text { Cuprissa- } \\
\text { ceae }\end{array}$ & $\begin{array}{l}\text { Tetraclinis articulata (Vahl.) } \\
\text { Masters }\end{array}$ & $\mathrm{C}$ & 11 & 12 & 5 & 3 & 8 & & Pignatti \\
\hline 60 & Juniperus oxycedrus L. & $\mathrm{A}$ & 8 & 8 & 5 & 3 & 5 & & $\begin{array}{l}\text { Pignatti } \\
\end{array}$ \\
\hline $\begin{array}{l}61 \text { Dipsaca- } \\
\text { ceae }\end{array}$ & Lomelosia stellata L. & B & 7 & 7 & 4 & 4 & 5 & & Pignatti \\
\hline 62 & Astragalus cruciatus Unk. & $\mathrm{A}$ & 9 & 8 & 4 & 3 & 5 & & Estimated \\
\hline 63 Fabaceae & Calicotome spinosa (L.) Link & $\mathrm{A}$ & 12 & 1 & 4 & 2 & 5 & & Pignatti \\
\hline 64 & Hippocrepis scabra DC. & $\mathrm{B}$ & 9 & 8 & 5 & 2 & 7 & & Pignatti \\
\hline 65 Fagaceae & Quercusilex L. & $\mathrm{A}$ & 2 & 9 & 4 & 3 & 5 & & Pignatti \\
\hline 66 Géraniacea & $\begin{array}{l}\text { Erodium glaucophyllum } \\
\text { eL'Her. }\end{array}$ & A & 11 & 12 & 6 & 2 & 7 & & Pignatti \\
\hline 67 & Geranium rotundifolium L. & $\mathrm{D}$ & 7 & 8 & 5 & 3 & 6 & & Pignatti \\
\hline 68 Hyacin- & Muscari comosum (L.) Mill. & $\mathrm{A}$ & 9 & 8 & 5 & 3 & 5 & & Pignatti \\
\hline 69 thaceae & $\overline{\text { Urginea maritima L. }}$ & $\mathrm{C}$ & 11 & 1 & 3 & 1 & 4 & & Pignatti \\
\hline 70 & Marrubium vulgare $\mathrm{L}$. & $\mathrm{B}$ & 9 & 8 & 5 & 3 & 8 & & Pignatti \\
\hline 71 & Mentha rotundifolia L. & $\mathrm{C}$ & 7 & 5 & 5 & 8 & 8 & & Pignatti \\
\hline$\frac{72}{1}$ & Rosmarinus officinalis L. & A & 1 & 8 & 4 & 2 & 6 & & Pignatti \\
\hline $73^{\mathrm{La}}$ & Salvia officinalis L. & $\mathrm{C}$ & 11 & 6 & 6 & 2 & 7 & & Pignatti \\
\hline$\overline{74}$ & S. verbenaca (L.) Briq. & $\mathrm{C}$ & 8 & 8 & 4 & 3 & 5 & & Pignatti \\
\hline 75 & Thymus ciliatus Desf. & $\mathrm{C}$ & 9 & 8 & 4 & 3 & 6 & & Estimated \\
\hline 76 Lauraceae & Laurus nobilis L. & $\mathrm{B}$ & 2 & 7 & 4 & 8 & 4 & & Pignatti \\
\hline 77 Malvaceae & Malva sylvestris L. & $\mathrm{A}$ & 8 & 6 & 4 & 4 & 5 & & Pignatti \\
\hline 78 Oleaceae & Phillyrea angustifolia L. & $\mathrm{C}$ & 11 & 1 & 4 & 1 & 5 & & Pignatti \\
\hline $\begin{array}{l}79 \text { Oroban- } \\
\text { chaceae }\end{array}$ & Orobanche crenata Forsk. & A & 8 & 5 & 6 & 3 & 5 & & Pignatti \\
\hline 80 Palmaceae & Chamaerops humilis L. & $\mathrm{A}$ & 11 & 1 & 3 & 1 & 4 & & Pignatti \\
\hline $\begin{array}{l}81 \text { Papave- } \\
\text { raceae }\end{array}$ & Papaver rhoeas L. & A & 6 & 6 & 5 & 5 & 7 & & Pignatti \\
\hline $\begin{array}{l}82 \text { Plantagi- } \\
\text { naceae }\end{array}$ & Globularia alypum L. & $\mathrm{C}$ & 11 & 8 & 4 & 2 & 2 & & Pignatti \\
\hline 83 & Aegilops geniculata Roth & $\mathrm{A}$ & 11 & 1 & 4 & 5 & 5 & & Pignatti \\
\hline 84 & $\begin{array}{l}\text { Ampelodesmos mauritanicus } \\
\text { (Poir.) T.Durand \& Schinz }\end{array}$ & A & 8 & 11 & 3 & 2 & 5 & & Pignatti \\
\hline 85 & Avena sativa L. & $\mathrm{B}$ & 8 & 7 & 6 & 5 & 6 & & Pignatti \\
\hline 86 & A. sterilis L. & $\mathrm{C}$ & 8 & 9 & 5 & 3 & 6 & 4 & Pignatti \\
\hline 87 & Aristida pungens Desf. & $\mathrm{A}$ & 10 & 8 & 5 & 3 & 5 & & Estimated \\
\hline 88 & Briza minor L. & $\mathrm{B}$ & 8 & 9 & 5 & 2 & 4 & & Pignatti \\
\hline$\overline{89}$ Poaceae & Bromus rubens L. & $\mathrm{C}$ & 8 & 11 & 5 & 2 & 5 & & Pignatti \\
\hline 90 & $\begin{array}{l}\text { Ctenopsis pectinella (Del.) } \\
\text { De Not. }\end{array}$ & $\mathrm{C}$ & 9 & 8 & 4 & 3 & 5 & 3 & Estimated \\
\hline 91 & Hordeum murinum L. & $\mathrm{A}$ & 8 & 8 & 4 & 5 & 5 & & Pignatti \\
\hline$\overline{92}$ & Lolium multiflorum Lam. & $\mathrm{A}$ & 7 & 7 & 5 & 4 & 5 & & Pignatti \\
\hline 93 & L. rigidum Gaud. & $\mathrm{C}$ & 8 & 8 & 5 & 3 & 4 & & Pignatti \\
\hline 94 & Lygeum spartum L. & $\mathrm{B}$ & 12 & 11 & 4 & 1 & 7 & 1 & Pignatti \\
\hline 95 & Stipa tenacissima L. & $\mathrm{A}$ & 9 & 8 & 4 & 3 & 5 & & Estimated \\
\hline 96 Primulacea & eAnagallis arvensis L. & $\mathrm{A}$ & 6 & 6 & 5 & 5 & 5 & 6 & Pignatti \\
\hline 97 Resedaceae & Reseda alba L. & A & 11 & 8 & 4 & 3 & 7 & & Pignatti \\
\hline $\begin{array}{l}98 \text { Rham- } \\
\text { naceae }\end{array}$ & Ziziphus lotus (L.) Lam. & $\mathrm{D}$ & 11 & 12 & 5 & 1 & 7 & & latti \\
\hline $\begin{array}{l}99 \text { Tamari- } \\
\text { caceae }\end{array}$ & Tamarix gallica L. & $\mathrm{C}$ & 11 & 7 & 4 & 6 & 5 & 3 & Pignatti \\
\hline $\begin{array}{l}\text { 100Thyme- } \\
\text { laeaceae }\end{array}$ & Thymelaea hirsuta (L.) Endl. & A & 11 & 8 & 5 & 2 & 5 & 3 & Pignatti \\
\hline 101Urticaceae & Urtica dioica $\mathrm{L}$. & $\mathrm{A}$ & 9 & 8 & 4 & 6 & 5 & 8 & Estimated \\
\hline $\begin{array}{l}102 \text { Valeria- } \\
\text { naceae }\end{array}$ & Valeriana tuberosa $\mathrm{L}$. & $\mathrm{C}$ & 11 & 4 & 5 & 5 & 7 & 3 & Pignatti \\
\hline $\begin{array}{l}\text { 103Zygophyl- } \\
\text { laceae }\end{array}$ & Peganum harmala L. & B & 12 & 12 & 6 & 1 & 7 & & Pignatti \\
\hline
\end{tabular}

Notes: FG - functional groups; $\mathrm{L}$ - light regime; $\mathrm{T}$ - temperatures; $\mathrm{K}$ continentality of climate; F-humidity; R-acidity; $\mathrm{N}$ - nutrients availability.

Indeed, the importance of the families that occupy the first places is explained by its adaptation to the various actions exerted on the environment. From a morphological point of view, the plant formations are marked by the heterogeneity between woody and herbaceous plants and between perennials and annuals.

The herbaceous annuals (HA) dominate with a percentage of $45.6 \%$, followed by perennial herbs (HV) $39.8 \%$ and finally, perennial woody (LV) with $14.6 \%$. The production of the raw biological spectra is based on the enumeration of the taxa by biological type and carried out on the totality of the species of each group. The determination of the 
biological types was carried out according to the method of Raunkiaer (1905). The plant structure of the study area is schematically represented as follows: $\mathrm{Th}>\mathrm{Ch}>\mathrm{He}>\mathrm{Ph}>\mathrm{Ge}$. Table 2 shows the results of the floristic composition according to the biological characterization.

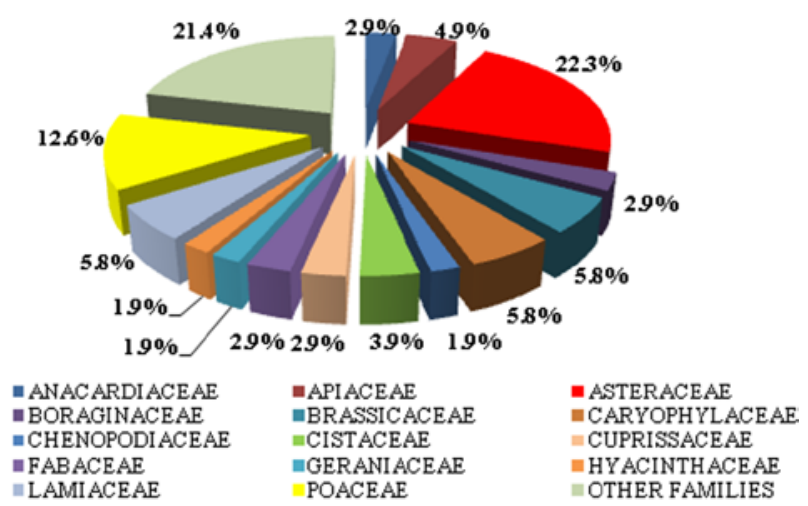

Fig. 2. Composition of the flora by family (\% from the total species number)

Table 2

Percentage of Raunkiaer plant life-forms

\begin{tabular}{lccccccc}
\hline Biological Types & Ph & Ch & He & Ge & Th & Total & Biological Spectrum \\
\hline Number of species & 10 & 19 & 18 & 9 & 47 & 103 & Th $>\mathrm{Ch}>\mathrm{He}>$ \\
Percentage (\%) & 9.7 & 18.4 & 17.5 & 8.7 & 45.6 & 100 & $\mathrm{Ph}>\mathrm{Ge}$ \\
\hline
\end{tabular}

Notes: Ph - phanerophytes; $\mathrm{Ch}$ - chamaephytes; He - hemicryptophytes; $\mathrm{Ge}$ - geophytes; Th - therophytes; source: authors personnal data

The results show that Therophytes (TH) have the highest level with $45.6 \%$, the most abundant species being Bellis sylvestris, Calendula arvensis, Chrysanthemum segetum, Sinapis arvensis, Malva sylvestris, Aegilops geniculata. Several authors agree that this therophytisation is linked to the harsh climate and to anthropogenic actions that are increasingly degrading the conditions for the colonisation of new species. Daget (1980) thinks that, in any case, the rate of therophytes is linked, whatever the scale of the analysis and the level of perception adopted, to the opening of the vegetation and to the overall humidity of the environment. The chamaephytes (Ch) represented mainly by Chamaerops humilis, Calycotome spinosa, Ampelodes mamauritanicum, Cistus monspeliensis, have a percentage of $18.4 \%$. These species shape the physiognomy of these ecosystems by adapting them to the xeric conditions of the environment. They have strong capacity to withstand the burden of animal overload and other forms of anthropogenic stress, mainly fires and cutting. The hemicryptophytes (He) occupy an important place. They occupy the third position in the plant formations studied. 18 species make up this group, i.e. $17.5 \%$. of all the species listed Among these species are: Eryngium campestre, Atractylis aristata, Carduus pycnocephalus, Echinops spinosus and Astragalus cruciatus. Phanerophytes $(\mathrm{Ph})$ mainly represented by hardwoods such as Quercus ilex, Pistacia atlantica, P. lentiscus, Phillyrea angustifolia and conifers such as Tetraclinis articulata, Juniperus oxycedrus and J. phoenica make up $9.7 \%$ of the species listed. Geophytes (Ge) are also present with 9 species (8.7\%). The aridity of the environment, coupled with the strong pressure exerted by man and his herds, causing important phenomena of water stress and adaptation (chemo and morphotactic) in plants, has led to the progressive invasion by plant groups dominated mainly by toxic species such as Asphodelus microcarpus, Urginea maritima, Urtica dioica or thorny plants such as Asparagus officenalis. The calculated perturbation index (PI) is of the order of $64.1 \%$. PI indicates the invasion of annual short-lived herbaceous plants; the latter express a strategy of adaptation to unfavourable conditions and a form of resistance to climatic rigours. On the other hand, perennial trees are more demanding in water and trophic needs.

The analysis of the species recorded by biogeographic types showed the predominance of Mediterranean biogeographic species with 20 species (19.8\%), West-Mediterranean and Eurasian types are represented by 7 species (6.9\%), followed by the North African endemics
4 species (4.1\%). The Palaeo-Tempere, European, Circum-Mediterranean and Cosmopolite elements occupy 5th position with three species (3.2\%). The other types represent a low participation: two species (2\%) as Circumboreal, one species (1.3\%) such as Saharan Mediterranean. Despite this low participation, these elements contribute to the phytogeographical diversity of the studied region.

Phytoecological analysis makes it possible to specify the effect of ecological factors on the dispersal, development, abundance and arrangement of plant species. Indeed, the distribution and the structure of the plant groups maintained close relations with the ecological environment. This part of the work presents the global approach which focuses mainly on statistical treatment of floristic survey tables in order to understand the dynamics of plant groups and to show ecological gradients.

Phytoindication provided an opportunity to establish the statistical characteristics of the variation of environmental factors within the study area (Table 3).

Table 3

Descriptive statistics of the phytoindicator assessed ecological factors

\begin{tabular}{lccccc}
\hline \multicolumn{1}{c}{ Ecological factor } & Median & Minimum & Maximum & Lower & Upper \\
\hline Light regime & 8.84 & 8.27 & 9.19 & 8.67 & 8.94 \\
Temperatures & 8.09 & 7.73 & 8.34 & 7.91 & 8.17 \\
Continentality of climate & 4.48 & 4.33 & 4.60 & 4.44 & 4.50 \\
Humidity & 2.86 & 2.67 & 3.02 & 2.72 & 2.90 \\
Acidity & 5.44 & 5.20 & 5.77 & 5.40 & 5.50 \\
Nutrients Availability & 2.89 & 2.70 & 3.14 & 2.85 & 3.03 \\
\hline
\end{tabular}

The results reveal that the plants represented in the community mostly prefer strongly lit places. Phytoindication shows a warm sub Mediterranean climate. Continentality corresponds to the sub-oceanic climate. It is found that the moisture regime is in the range from strongly dry to dry soil. The plant community is formed on moderately acid soils. Plants are able to grow on both strongly acidic and neutral soils. The soil is very poor or poor in nitrogen.

Environmental factors can be used to determine the optimal solution for the ordination of plant communities using the method of multidimensional scaling. The methodological approach is that of all the possible ecological distances within data matrix plants/sites and transformation methods, the one that gives the highest correlation with environmental factors should be selected. Spearman rank correlations coefficients between dissimilarity indices and gradient separation with different data transformation methods have revealed that usage of divided by margin total data and Euclidean distance is the most appropriate approach to reflect the relationship between soil mechanical impedance and ecological factors (Table 4). In further calculations the experimental data will be used in the above-mentioned transformed way.

Stress is a goodness-of-fit statistic in multidimensional scaling based on the differences between the actual distances and their predicted values. One of the goals of multidimension scaling analysis is to keep the number of dimensions as small as possible. The usual technique is to solve the multidimensional scaling problem for a number of dimension values and adopt the smallest number of dimensions that achieves a reasonably small value of stress. An appropriate number of dimensions was chosen by performing ordinations of progressively higher numbers of dimensions. A stress versus number of dimensions screen diagram was then plotted, on which one can identify the point beyond which additional dimensions do not substantially lower the stress value (Fig. 6). A four dimension variant of multidimensional scaling procedure was selected as the most appropriate decision.

Four dimensions selected after nonmetric multidimensional scaling (NMDS) were interpreted by computing weighted average scores of ecological factors for ordination configuration (Table 5).

It has been established that such predictors as light regime, temperatures, humidity, and acidity are statistically significant. They are able to explain from $42 \%$ to $48 \%$ of the dimension variation. The dimension MDS1 may be interpreted as the measure of the soil acidity which is controversially correlated with light regime. The dimension MDS2 is most sensitive to controversial correlation of the humidity on the one hand and temperature on the other. The dimension MDS3 is most sensitive to the soil acidity. The dimension MDS4 is most sensitive to the soil humidity. 
Table 4

Spearman rank correlation coefficients between dissimilarity indices and gradient separation with different data transformation methods

\begin{tabular}{|c|c|c|c|c|c|c|c|c|c|c|c|}
\hline \multirow{2}{*}{ Distance } & \multicolumn{11}{|c|}{ Data transformation methods } \\
\hline & 1 & 2 & 3 & 4 & 5 & 6 & 7 & 8 & 9 & 10 & 11 \\
\hline Euclidean & -0.32 & 0.33 & 0.34 & 0.46 & 0.11 & 0.10 & 0.43 & 0.17 & 0.44 & 0.39 & 0.31 \\
\hline Manhattan & -0.28 & 0.33 & 0.32 & 0.40 & 0.13 & 0.15 & 0.35 & 0.16 & 0.39 & 0.34 & 0.14 \\
\hline Gower & -0.16 & 0.28 & 0.25 & 0.25 & 0.16 & 0.16 & 0.05 & 0.16 & 0.28 & 0.25 & 0.14 \\
\hline Bray-Curtis & -0.40 & 0.39 & 0.40 & 0.40 & 0.28 & 0.31 & 0.39 & 0.31 & 0.39 & 0.36 & 0.14 \\
\hline Kulczynski & -0.42 & 0.40 & 0.41 & 0.40 & 0.30 & 0.33 & 0.40 & 0.32 & 0.39 & 0.37 & 0.14 \\
\hline Morisita & -0.43 & NA & 0.10 & -0.10 & -0.16 & -0.02 & -0.34 & -0.12 & -0.27 & -0.12 & -0.01 \\
\hline Horn-Morisita & -0.43 & 0.43 & 0.44 & 0.43 & 0.27 & 0.29 & 0.43 & 0.30 & 0.44 & 0.40 & 0.27 \\
\hline Cao & -0.33 & 0.22 & 0.25 & NA & 0.25 & 0.33 & 0.44 & 0.32 & 0.45 & 0.36 & NA \\
\hline Jaccard & -0.40 & 0.39 & 0.40 & 0.40 & 0.28 & 0.31 & 0.39 & 0.31 & 0.39 & 0.36 & 0.14 \\
\hline Mountford & -0.29 & 0.29 & 0.29 & 0.29 & 0.29 & 0.29 & 0.29 & 0.39 & 0.29 & 0.29 & 0.29 \\
\hline Raup-Crick & -0.08 & -0.08 & -0.08 & -0.08 & -0.08 & -0.08 & -0.08 & -0.09 & -0.08 & -0.08 & -0.08 \\
\hline Canberra & -0.30 & 0.28 & 0.28 & 0.26 & 0.30 & 0.30 & 0.21 & 0.38 & 0.27 & 0.26 & 0.14 \\
\hline Chao & -0.04 & 0.04 & 0.04 & 0.16 & NA & 0.11 & 0.16 & NA & 0.19 & 0.08 & 0.07 \\
\hline Mahalanobis & -0.09 & 0.11 & 0.11 & 0.19 & 0.14 & 0.09 & 0.09 & 0.13 & 0.16 & 0.15 & 0.15 \\
\hline
\end{tabular}

Notes: bold marked the highest correlation coefficient; NA - not available; 1 - untransformed data; 2 - log-transformed data; 3 - square-root transformed data; 4 - divided by margin total; 5 - divided by margin maximum; 6 - divided by margin maximum and multiplied by the number of non-zero items, so that the average of non-zero entries is one; 7 - normalized (margin sum of squares equal to one); 8 -standardized values into range $0-1 ; 9$ - Hellinger transformation; $10-\chi^{2}$-transformation; 11 Wisconsin transformation.

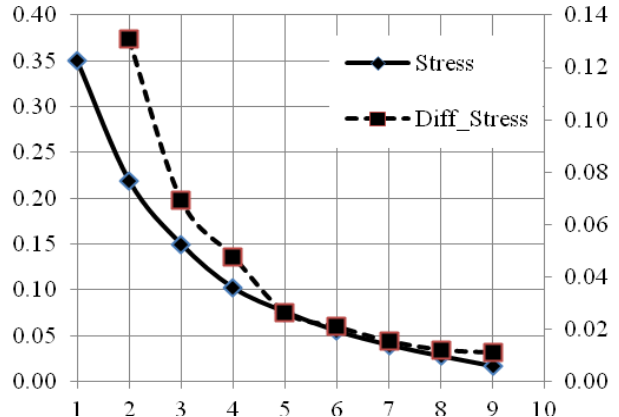

Fig. 6. Stress versus number of dimensions screen diagram: arrow shows optimal number of dimensions: abscissa - the number of dimensions; ordinate - stress (left axis) or differential stress (right axis)

Table 5

Fitting environmental factors onto an ordination

\begin{tabular}{lrrrrrrr}
\hline Ecological factors & \multicolumn{1}{c}{ MDS1 MDS2 MDS3 } & MDS4 $r^{2}$ & $\operatorname{Pr}(>r) \begin{array}{c}\text { Significance } \\
\text { codes }\end{array}$ \\
\hline Light Regime & 0.58 & -0.73 & -0.15 & 0.33 & 0.48 & 0.00 & $* * *$ \\
Temperatures & -0.26 & -0.84 & 0.37 & -0.30 & 0.48 & 0.00 & $* *$ \\
Continentality of & -0.77 & -0.26 & 0.25 & -0.53 & 0.07 & 0.79 & n.s. \\
Climate & 0.12 & 0.74 & 0.13 & -0.65 & 0.42 & 0.01 & $* *$ \\
Humidity & -0.70 & -0.38 & 0.53 & -0.30 & 0.44 & 0.01 & $* *$ \\
Acidity & 0.60 & -0.53 & 0.19 & 0.57 & 0.21 & 0.21 & n.s. \\
Nutrients Availability & 0.19 &
\end{tabular}

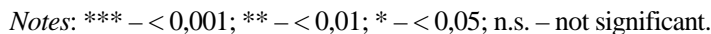

Fitting environmental factors onto an ordination by means of linear models is quite far from the real character of the relation between ecological factors and community stricture. Smoothing surface for some ecological factors within the ordination diagram shows a complicated and nonlinear response of the vegetation due to ecological factors impact (Fig. 7). As shown in the figures, the linear coefficients indicate only a priority trend in the changes in the plant community structure.

Multidimensional scaling allows us to estimate how placement of sampling points, and plant species in the same space. Measured values for the plant can be used for cluster analysis of the plant community. An important aspect of cluster analysis is to identify the optimal number of clusters. This problem was solved by means of Calinsky-Harabasz criteria (Fig. 8). Four of the clusters were found to be the optimal solution. Cluster solution can be represented as a dendrogram (Fig. 9). Also ellipsoids can designate the configuration of species that belong to one cluster, in the dimension space (Fig. 10).

The clusters can be viewed as a functional group. The information obtained allows us to interpret the functional groups in terms of their environmental characteristics. Functional group A is a closest to the community optimum because in all four space dimensions the corresponding cluster is near the origin, which corresponds to the most typical ecological conditions. This functional group is a quite diverse. The functional group A comprises 42 species. Species that constitute the group B prefer minimum values of dimension 2 . This indicates a preference for illuminated sites with high temperature regime and low soil humidity. Thus, the functional group B is species of open dry spaces. This group includes 32 species. The main feature of group $\mathrm{C}$ is that it is located in the area of maximum values for dimension 2 . Thus, this functional group is opposite to functional group B. This indicates the preference of species included in the functional group $\mathrm{C}$ forf wetter soils. Functional group C comprises 21 species. Functional group D most considerably differs from all others in its ecological characteristics. The difference is in the preference for minimum values for measurement 1 . This suggests that more acidic soils are optimal for a given functional group. Functional group E comprises 8 species.
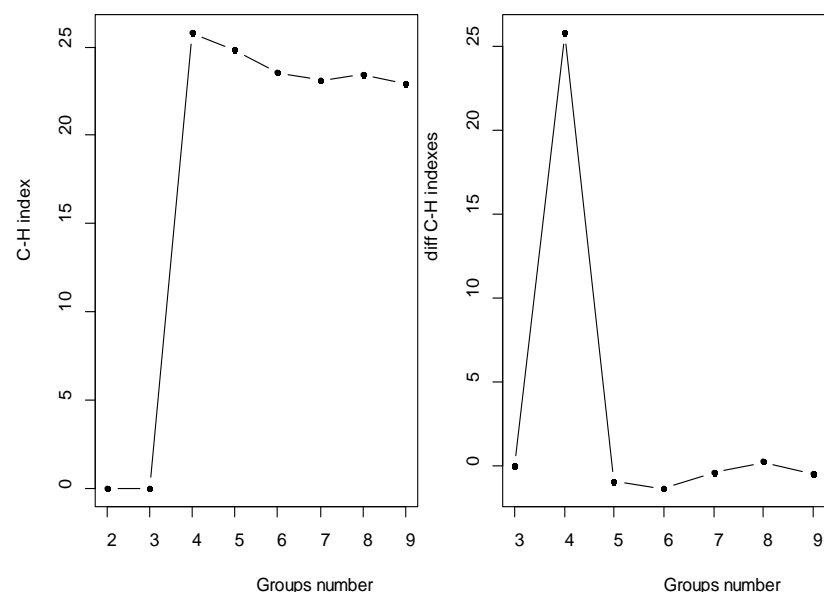

Fig. 8. Usage of the Calinsky-Harabasz criteria (C-H index) to find the best vegetation community partition

\section{Discussion}

Structures of plant communities can be identified through ordination (Pélissier et al., 2003). Among the many approaches to community ordination, multidimensional scaling can be considered as one of the most appropriate tools (Zhukov, 2015). One of its advantages is that it uses a great diversity of distance measures and methods of data pretransformation (Allen et al., 1984). However, this feature creates difficulties associated with the optimal choice solutions. This problem can 
be solved by maximizing the correlation matrix of measures distances between species in community and ecological properties of the environ- ment. This approach allowed us to establish that for the studied community Euclidean distance is the best measure of distance.
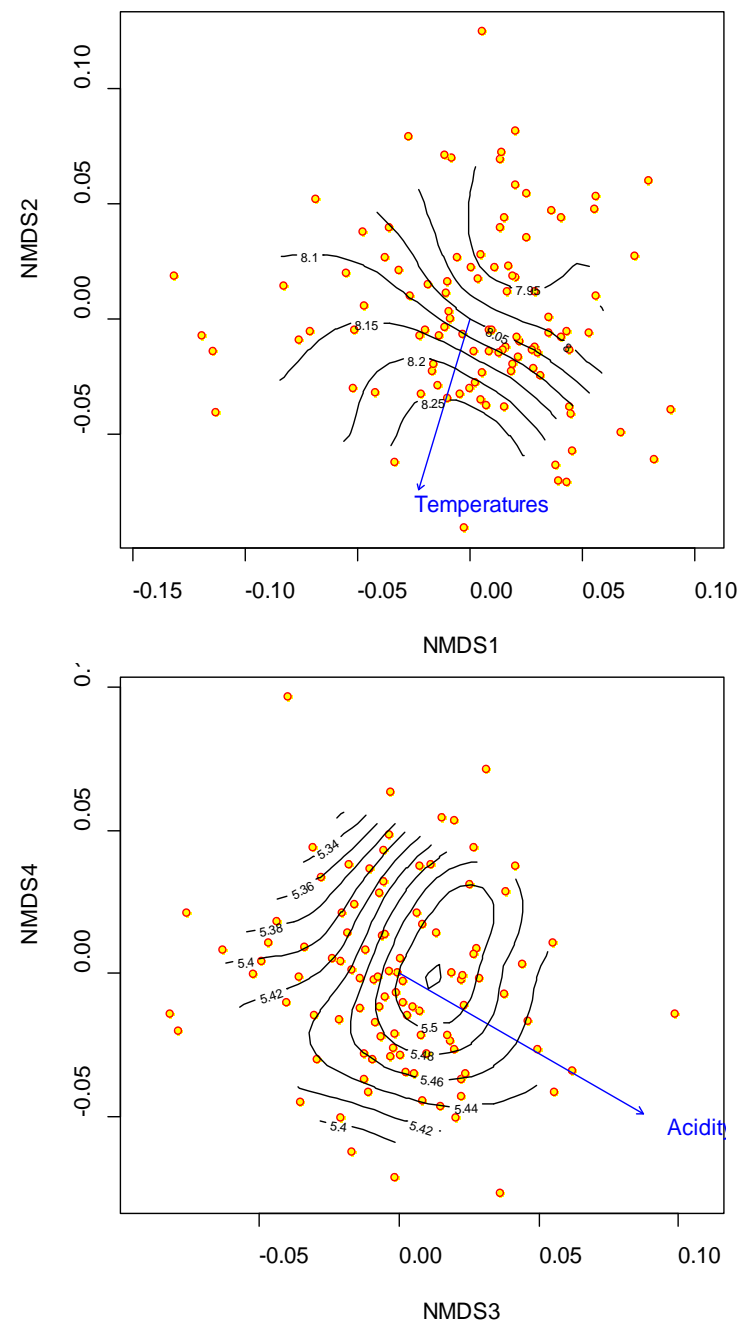

Fig. 7. Smoothing surface for some ecological factors within ordination diagram

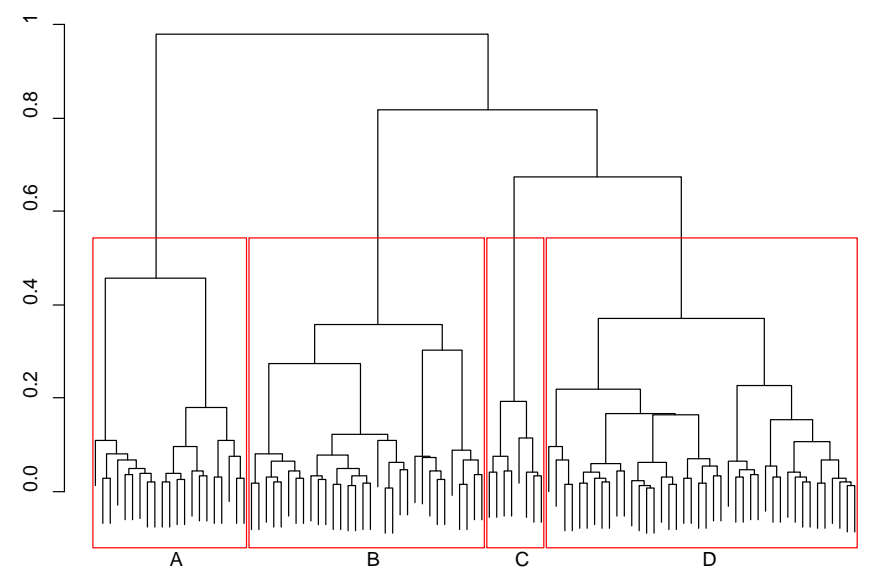

Fig. 9. Vegetation community cluster analysis (Ward method, Euclidian distance). A, B, C, D-clusters (functional groups)

The phytoindication method was applied as a source of information on ecological factors. This approach has independent significance. We have obtained a quantitative assessment of the ecological factors that may affect the structure of the community. Vegetation classification made it possible to establish the existence of four functional groups.

Functional group $\mathrm{A}$ is a quite diverse and represented by 42 species. In this group we notice the installation of a tree formation consisting mainly of Quercus ilex, Junepirus oxycedrus, J. phoenica, Pistacia lentiscus and Tetraclinis articulata. This formation represents the limit of the wooded vegetation of the Djebel Nador massif. Deviation from the conditions favourable to the functional group leads to the impossibility of the existence of forest vegetation (Brygadyrenko, 2015; 2016). We observed the colonisation of certain species that mark anthropization (Chamaerops humilis). It should be noted that the diversity of this group is also due to the presence of herbaceous plants such as Stipa tenacissima, Artemisia herba-alba, Hordeum murinum. Therophyte species are represented by Taraxacum obovatum and Bellis sylvestris. We also noted the presence of species that dominate by their biomass such as Stipa tenacissima. 


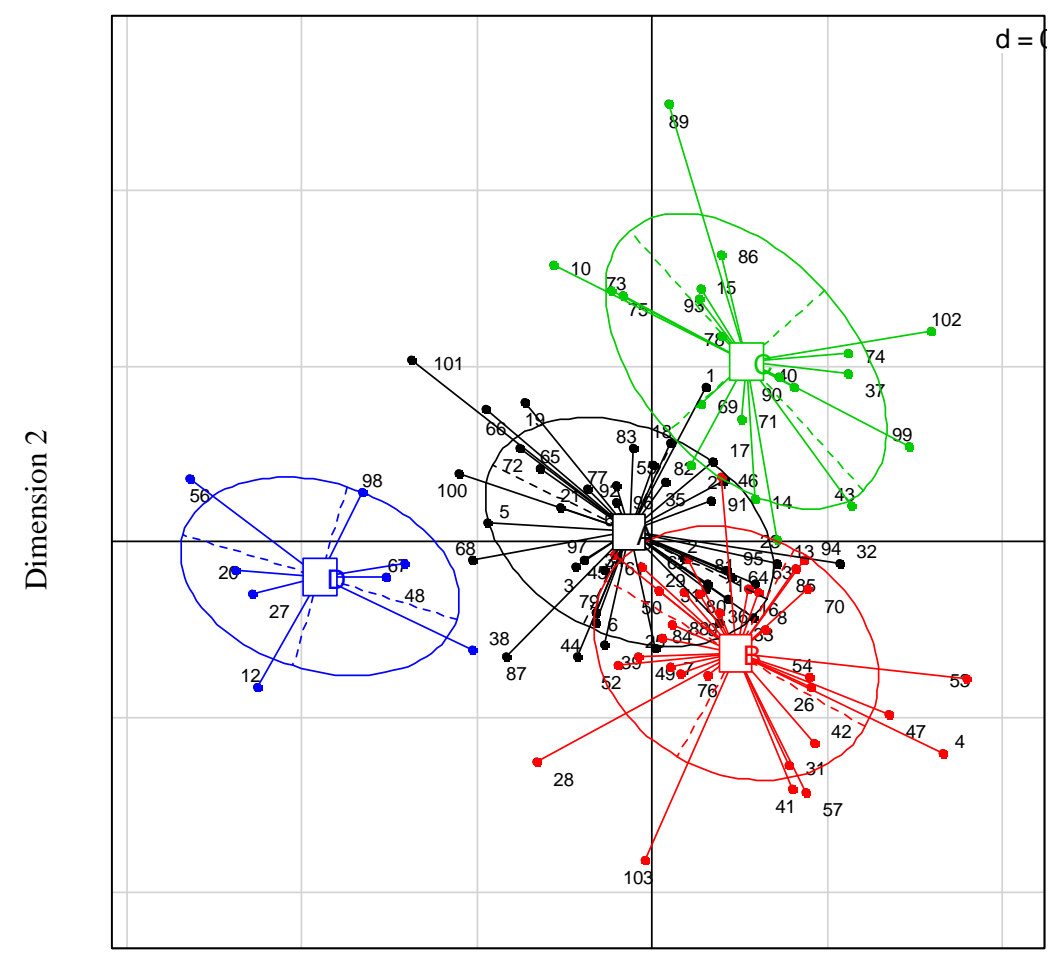

Dimension 1

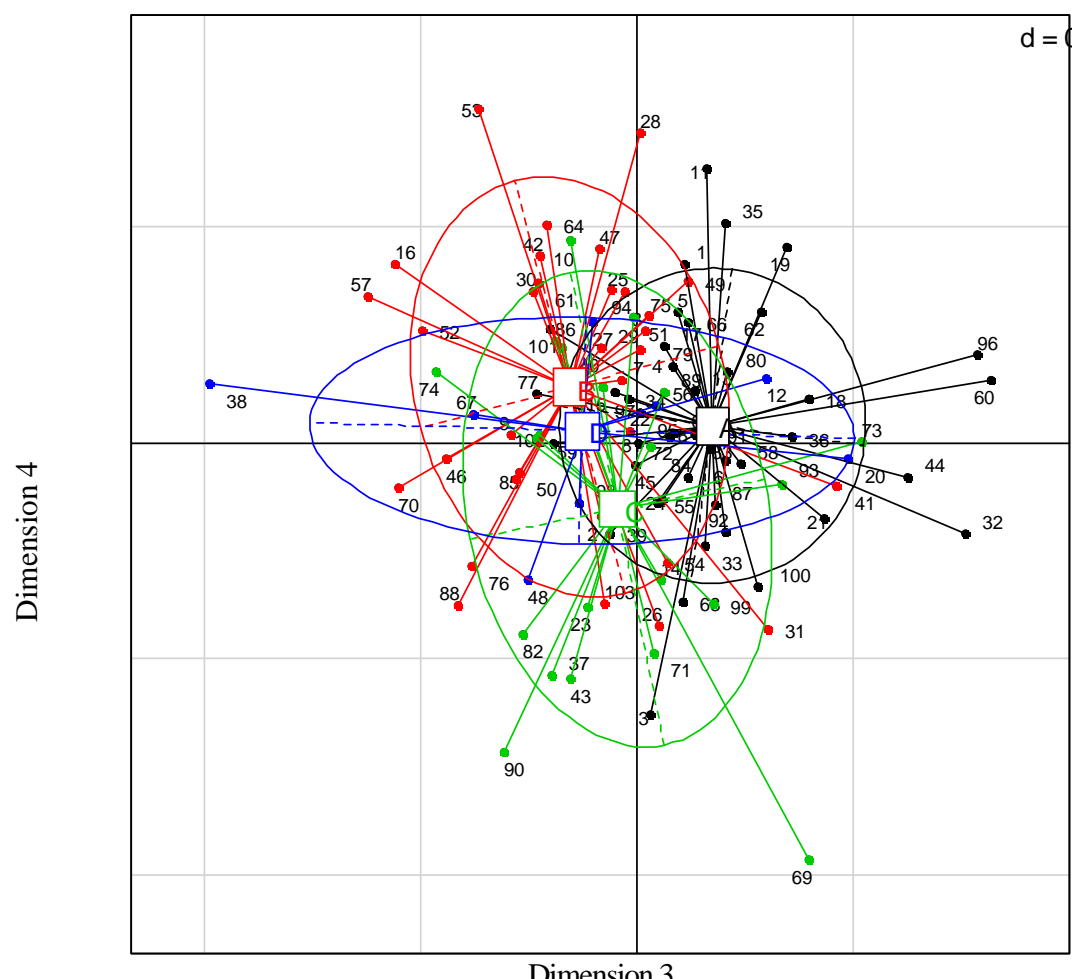

Dimension 3

Fig. 10. Species distribution and cluster configuration in multidimensional space: 1 - Allium subhirsutum; 2 - Pistacia atlantica; 3 - Pistacia lentiscus; 4 - Pistacia terebinthus; 5 -Ammi majus; 6 - Bupleurum rotundifolium; 7 - Daucus carota; 8 -Eryngium campestre; 9 - Ferula communis; 10 - Asparagus officinalis; 11 - Asphodelus microcarpus; 12 - Anacyclus cyrtolepidioides; 13 - Artemisia herba-alba; 14-Atractylis aristata; 15-Atractylis cancellata; 16 - Atractylis humilis; 17 - Atractylis carduus; 18 - Bellis sylvestris; 19 - Calendula arvensis; 20 - Carduus nutans; 21 - Carduus pycnocephalus; 22 - Carlina gummifera; 23 - Catananche caerulea; 24 - Centaurea pullata; 25 - Glebionis segetum; 26 - Echinops spinosus; 27 - Hypochaeris radicata; 28 - Launaea arborescens; 29 - Leucanthemum paludosum; 30 - Matricaria chamomilla;

31 - Scolymus hispanicus; 32 - Podospermum laciniatum; 33 - Taraxacum obovatum; 34 - Artemisia campestris; 35 - Borago officinalis;

36 - Echium pycnanthum; 37 - Lappula redowskii; 38 - Alyssum granatense; 39 - Lepidium draba; 40 - Matthiola lunata; 41 - Matthiola parviflora; 42 - Sisymbrium irio; 43 - Sinapis arvensis; 44 - Paronychia arabica; 45 - Paronychia argentea; 46 - Silene gallica; 47 - Sclerocephalus arabicus; 48 - Silene vulgaris; 49 - Telephium sphaerospermum; 50 - Chenopodium murale; 51 - Haloxylon scoparium; 52 - Cistus albidus; 53 - Cistus monspeliensis; 54 - Helianthemum hirtum; 55 - Helianthemum helianthemoides; 56 - Convolvulus althaeoides; 57 - Sedum album; 58 - Juniperus phoenicea; 59 - Tetraclinis articulata; 60 - Juniperus oxycedrus; 61 - Lomelosia stellata; 62 - Astragalus cruciatus; 63 - Calicotome spinosa; 64 - Hippocrepis scabra; 65 - Quercus ilex; 66 - Erodium glaucophyllum; 67 - Geranium rotundifolium; 
68 - Ferula communis; 69 - Urginea maritima; 70 - Marrubium vulgare; 71 - Mentha rotundifolia; 72 - Rosmarinus officinalis; 73 - Salvia officinalis; 74 - Salvia verbenaca; 75 - Thymus ciliatus; 76 - Laurus nobilis; 77 - Malva sylvestris; 78-Phillyrea angustifolia; 79-Orobanche crenata; 80 - Chamaerops humilis; 81 - Papaver rhoeas; 82 - Globularia alypum; 83 - Aegilops geniculata; 84-Ampelodesmos mauritanicus; 85-Avena sativa; 86 - Avena sterilis; 87 - Aristida pungens; 88 - Briza minor; 89 - Bromus rubens; 90 - Ctenopsis pectinella; 91 - Hordeum murinum; 92 - Lolium multiflorum; 93 - Lolium rigidum; 94 - Lygeum spartum; 95 - Stipa tenacissima; 96 - Anagallis arvensis; 97 - Reseda alba;

98 -Ziziphus lotus; 99 - Tamarix gallica; 100 - Thymelaea hirsuta; 101 - Urtica dioica; 102 - Valeriana tuberosa; 103 - Peganum harmala

Among annual species are several ruderal species (Reseda alba). Thus, woody, shrubby or herbaceous communities can be similar in their environmental conditions of habitat. According to Le-Houerou (1995), ovine and bovine overgrazing leads to the development of chamaephytes and their proportion increases as soon as degradation of pre-forestry environments occurs, as this biological type adapts better to summer drought and light than phanerophytes. Another gradient of degradation in steppe formations (Stipa tenacissima and Lygeum spartum) by the invasion of annual short-life species (therophytes), this therophytization is a form of resistance to climatic rigours. Thus, anthropization, grazing enriches the soil with nitrates and allows the development of ruderals, in particular annuals (Barbero et al., 1990).

The functional group B (32 species) is characterized by the total absence of phanerophytic species and the dominance of chamaephytes such as Peganum harmala, Ferula communis, Laurus nobilis. Hemicryptophytes are represented by Eryngium campestre, Telephium sphaerospermum and finally four therophyte species: Lomelosia stellata, Daucus carota, Avena sativa and Silene gallica. We also noted the presence of species that dominate by their biomass such as Lygeum spartum. We observed the colonisation of certain species that mark anthropization (Atractylis humilis). In a multidimensional space functional group $B$ occupies the lower right square. This region corresponds to the dry habitats with a high insolation level. Probably, dryness and intense lighting is a consequence of the presence of sparse grass cover. The reason for this can be seen in the variability of edaphic properties, which is reflected in increasing their acidity. Such edaphic conditions limit the significant development of vegetation. It should be noted that the overall level of soil nutrients is not high and does not act as a significant environmental factor, which is able to differentiate vegetation.

The functional group C (21 species) is dominated by thererophytes such as Catananche caerulea, Bromus rubens, etc. Geophytes are represented by Asphodelus microcarpus and Urginea maritima. Hemicryptophytes are represented by Valeriana tuberosa. Among annual species Convolvulus althaeoides is a ruderal plant. Soil moisture regime leads to the differentiation of functional group $(C)$ from the rest of the vegetation types.

The functional group D (8 species) is dominated by Anacyclus cyrtolepidioides, Hypochaeris radicata, Silene vulgaris. Therophytes are presented by Geranium rotundifolium, Alyssum granatense. Ziziphus lotus marks anthropization. Among annual species are several ruderal species (Convolvulus althaeoides, Carduus nutans). Plants develop along the edges of fields of cereals and fodder to the detriment of the natural species whose germination had been triggered by plowing. These crops play a role in the life of herders, since they represent a secondary financial contribution besides raising livestock.

\section{Conclusion}

The results obtained from this study show a change in the physiognomy of the studied flora caused by aridity of the climate (insufficiency and irregularity of precipitation) associated with the increase in anthropic activities (cutting, clearing, overgrazing and fires). There has been a degradation of forest and pre-forestry groups and their replacement by plant species adapted to climatic and anthropogenic stresses. There is a proliferation of species indicative of environmental degradation by anthropozoic agents such as Ziziphus lotus, Urginea maritima, Ferula communis, Asphodelus microcarpus, Peganum harmala, etc.

Finally, it can be pointed out from this contribution that the flora of the study area is in a regressive dynamic where several phenomena have left a strong imprint on these natural ecosystems. We suggest that it will be necessary in the future to make a follow-up survey, paying special attention to vulnerable species.

\section{References}

Allen, T. F. H., Sadowsky, D. A., \& Woodhead, N. (1984). Data transformation as a scaling operation in ordination of plankton. Vegetatio, 56, 147-160.

Ashby, E. (1936). Statistical ecology. The Botanical Review, 2, 221-235.

Austin, M. P. (2013). Vegetation and environment: Discontinuities and continuities. In: van der Maarel, E., \& Franklin, J. (ed.). Vegetation Ecology. Second edition. John Wiley \& Sons, Ltd. pp. 52-84.

Barbero, M., Quezel, P., \& Loisel, R. (1990). Les apports de la phyto-écologie dans l'interprétation des changements et perturbations induits par l'homme sur les écosystèmes forestiers méditerranéens. Forêt Méllitertanéenne, 12, 194-215.

Benabadji, N., \& Bouazza, M. (2001). L'impact de l'homme sur la forêt dans la région de Tlemcen. Forêt Méllitertanéenne, 22(3), 269-274.

Benabadji, N., Benabadji Bouchenak-Khelladi, A., Regagba, Z., \& Medarbal, K., (2014). Some anthropic aspects in Meridional Region of Sebdou (OranAlgeria). Open Journal of Ecology, 4, 678-692.

Benabid, A. (1984). Etudes phytosociologique et phytodynamique et leurs utilites. Annales de la Recherche Forestière au Marocco, 24, 3-35.

Benkhettou, A., Azouzi, B., Djili, K., Benkhettou, M., Zedek, M., \& Saadi, R. (2015). Diversité floristique du massif du Nador en zone steppique (Tiaret, Algérie). European Scientific Journal, 21, 401-419.

BraurBlanque,tJ., RoussinẹN., Nègre R., \& Emberger, L. (1951). Les groupements végétaux de la France méditerranéenne. C. N. R. S., Paris.

Brygadyrenko, V. V. (2015). Vplyv umov zvolozhennja ta mineralizaciji gruntovogo rozchynu na strukturu pidstylkovoji mezofauny shyrokolystjanyh lisiv stepovoji zony Ukrajiny [Influence of moisture conditions and mineralization of soil solution on structure of litter macrofauna of the deciduous forests of Ukraine steppe zone]. Visnyk of Dnipropetrovsk University. Biology, Ecology, 23(1), 50-65 (in Ukrainian).

Brygadyrenko, V. V. (2016). Evaluation of ecological niches of abundant species of Poecilus and Pterostichus (Coleoptera: Carabidae) in forests of the steppe zone of Ukraine. Entomologica Fennica, 27(2), 81-100.

Daget, P., (1980). On the biological types as adaptive strategy (Case of therophytes). In: Barbault, R., Blandin, P., \& Meyer, J. A. (Eds.). Searching theoretical ecology, adaptive strategies. Maloine, Paris. pp. 89-114.

Diekmann, M. (2003). Species indicator values as an important tool in applied plant ecology - A review. Basic and Applied Ecology, 4(6), 493-506.

Dray, S., \& Dufour, A. B. (2007). The ade4 package: Implementing the duality diagram for ecologists. Journal of Statistical Software, 22(4), 1-20.

Hachemi, N., Hasnaoui, O., Benmehdi, I., Medjati, N., \& Bouazza, M. (2012). Contribution à l'étude de la thérophytisation des matorrals des versants sud des monts de Tlemcen (Algérie occidentale). Mediterranea (serie de estudios biológicos), 23(2), 158-180.

Hasnauoi, O., \& Bouazza, M. (2015). Indicateurs De dégradation des bio-ressources naturelles de l'Algérie occidentale: Cas de la steppe de la wilaya de saida. Algerian Journal of Arid Environment, 5(1), 63-75.

Hill, M. O., Mountford, J. O., Roy, D. B., \& Bunce, R. G. H. (1999). Ellenberg's indicator values for British plants. Huntingdon, Institute of Terrestrial Ecology.

Horsák, M., Hájek, M., Tichý, L., \& Juřičková, L. (2007). Plant indicator values as a tool for land mollusc autecology assessment. Acta Oecologica, 32(2), 161-171.

Landolt, E. (1977). Ökologische Zeigerwerts zur Schweizer Flora. Veröff. Geobot. Inst. ETH. Zurich, 64, 1-208.

Legendre, P., \& Gallagher, E. D. (2001). Ecologically meaningful transformations for ordination of species. Oecologia, 129(2), 271-280.

Le-Houerou, H. N. (1995). Bioclimatologie et biogéographie des steppes arides du Nord de l'Afrique. Diversité biologique, développement durable et désertisation. Option Méditerranéennes Sér. B, 10.

Loisel, R., \& Gamila, H. (1993). Traduction des effets du débroussaillement sur les écosystèmes forestiers et pré-forestiers par un indice de perturbation. Annales de la Société des Sciences Naturelles et d'Archéologie de Toulon et du Var, 123-132.

Minchin, P. R. (1989). Montane vegetation of the Mt. Field Massif, Tasmania: A test of some hypotheses about properties of community patterns. Vegetatio, 83, 97-110.

Oksanen, J., Blanchet, F. G., Kindt, R., Legendre, P., Minchin, P. R., O’Hara, R. B., Simpson, G. L., Solymos, P., Stevens, M. H. H., \& Wagner, H. (2017). Community Ecology Package. R package. 
Pélissier, R., Couteron, P., Dray, S., \& Sabatier, D. (2003). Consistency between ordination techniques and diversity measurements: Two strategies for species occurrence data. Ecology, 84, 242-251.

Pignatti, S., Menegoni, P., \& Pietrosanti, S. (2005). Bioindicazione attraverso le piante vascolari. Valori di indicazione secondo Ellenberg (Zeigerwerte) per le specie della Flora d'Italia. Braun-Blanquetia, 39, 1-97.

Quézel, P., \& Santa, S. (1962). Nouvelle Flore de l’Algérie et des régions désertiques méridionales. Thom 1-2. C. N. R. S., Paris.

Quézel, P., Barbero, M., Bonin, G., \& Loisel, R. (1980). Essai de corrélations phytosociologiques et bioclimatiques entre quelques structures actuelles et passées de la végétation méditerranéenne. Naturalia Monspelliensis, 79-87.

R Core Team (2016). R: A language and environment for statistical computing. R Foundation for Statistical Computing, Vienna.

Raunkiaer, C. (1905). Types biologiques pour la géographie botanique. Bulletin Académique, Revue Scientifique Danemark, 347-437.

Seidling, W., \& Fischer, R. (2008). Deviances from expected Ellenberg indicator values for nitrogen are re lated to $\mathrm{N}$ throughfall deposition in forests. Ecological Indicators, 8(5), 639-646.
Stambouli-Meziane, H., \& Bouazza, M. (2012). Anthropogenic effects on plant cover in the Tlemcen region (Western Algeria). Open Journal of Ecology, 3, 141-146.

ter Braak, C. J. F., \& Gremmen, N. J. M. (1987). Ecological amplitudes of plant species and the internal consistency of Ellenberg's indicator values for moisture. Vegetatio, 69, 79-87.

ter Braak, C. J. F., \& Looman, C. W. N. (1986). Weighted averaging, logistic regression and the Gaussian response model. Vegetatio, 65, 3-11.

Vitasović Kosić, I., Juračak, J., \& Łuczaj, L. (2017). Using Ellenberg-Pignatti values to estimate habitat preferences of wild food and medicinal plants: An example from northeastern Istria (Croatia). Journal of Ethnobiology and Ethnomedicine, 13, 31.

Zarzycki, K. (1984). Indicator values of vascular plants in Poland. Instytut Botaniki Polska Akademia Nauk, Krakow.

Zhukov, A. V. (2015). Phytoindicator estimation of the multidimensional scaling of the plant community structure. Biological Bulletin of Bogdan Chmelnitskiy Melitopol State Pedagogical University, 1(1), 69-93.

Zhukov, A., \& Zadorozhnaya, G. (2016). Spatial heterogeneity of mechanical impedance of a typical chernozem: The ecological approach. Ekológia (Bratislava), 35, 263-278. 